\title{
Cryopreserved sperm for oocyte fertilization of dourado Salminus brasiliensis
}

\author{
Sêmen criopreservado na fertilização de ovócitos de dourado Salminus brasiliensis
}

\author{
Marcos Weingartner ${ }^{\mathrm{I}}$ Ana Carolina Volpato Zanandrea ${ }^{\text {II }}$ Evoy Zaniboni FilhoII
}

\section{ABSTRACT}

Salminus brasiliensis is a migratory fish that has attracted considerable interest for aquaculture. Several procedures for induced spawning are known; however, there is a lack of protocol which enables the use of cryopreserved semen. Therefore, this study was conducted to investigate the use of cryopreserved semen using different volumes of cryopreserved semen relative to oocytes, different activators solutions and different maintenance time during the fertilization of dourado to evaluate the impact of these parameters on the fertilization rate. The semen was collected, cryopreserved in $0.5 \mathrm{~mL}$ straws and stored in a dry shipper. Oocytes samples were fertilized according to each treatment. The different activator solutions and the contact times of the gametes with activators affected significantly the fertilization rates, which ranged between 13.4 and $27.8 \%$, while fresh semen fertility rate was $80.8 \%$. The relationship between oocyte and cryopreserved semen was significant, being the best ratio $0.05 \mathrm{~mL}$ of cryopreserved semen per $10 \mathrm{~g}$ of oocytes, while upper or lower volumes promoted a reduction in fertilization. The use of cryopreserved semen was effective to fertilize $\boldsymbol{S}$. brasiliensis oocytes, however produced lower fertility rate than fresh semen.

Key words: frozen semen, gamete ratio, semen activation, activator solution.

\section{RESUMO}

O dourado, Salminus brasiliensis, é um peixe migrador que tem despertado interesse para piscicultura. Os procedimentos convencionais para a sua reprodução são conhecidos, contudo, falta um protocolo para o uso do sêmen criopreservado. Dessa forma, objetivou-se avaliar diferentes volumes de sêmen criopreservado, ouso de diferentes soluções ativadoras e com diferentes tempos de contato do sêmen com os ovócitos na taxa de fertilização. Para tal, o sêmen foi coletado e criopreservado em palhetas de $0,5 \mathrm{~mL}$ em vapor de nitrogênio líquido. Amostras de ovócitos foram fertilizadas conforme os distintos tratamentos. As diferentes soluções testadas e o tempo de contato dos ativadores afetaram significativamente as taxas de fertilização, com valores que variaram entre $13,4 \mathrm{e}$ $27,8 \%$, enquanto o sêmen fresco propiciou $80,8 \%$ de taxa de fertilização. $O$ volume de sêmen criopreservado afetou a taxa de fertilização dos ovos, sendo 0,05mL para $10 \mathrm{~g}$ de ovócitos, o que promoveu os melhores resultados, sendo que volumes superiores e inferiores promoveram redução na fertilização. $O$ uso de sêmen criopreservado foi efetivo na fertilização dos ovócitos de dourado, no entanto, foram obtidas taxas de fertilização inferiores àquelas observadas com o uso de sêmen fresco.

Palavras-chave: sêmen congelado, proporção de gametas, ativação espermática, solução ativadora.

\section{INTRODUCTION}

In Brazil, researches on the development of technology for cryopreservation semen of native species was intensified during the 1990s, being first driven by the goal of preserving the genetic variability of wild populations that could be impacted by the construction of hydroelectric dams and habitat degradation (VIVEIROS \& GODINHO, 2009).

For aquaculture, cryopreservation techniques allow to maximize the use of the male, due to successive collections of semen during the breeding season, which increases the semen production per male. This practice reduces the number of males required for the reproduction

\footnotetext{
'Engenharia de Aquicultura, Universidade Federal da Fronteira Sul (UFFS), Campus Laranjeiras do Sul, BR-158, km 07, 85301-970, Laranjeiras do Sul, PR, Brasil. E-mail: marcos.weingartner@uffs.edu.br. Autor para correspondência.

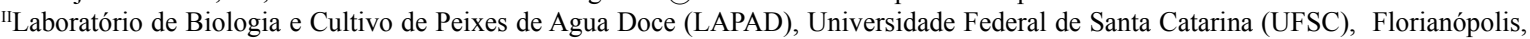
$\mathrm{SC}$, Brasil.
} 
and, consequently, reduces the cost for maintaining a broodstock (NASCIMENTO et al., 2010). This technique also facilitates genetic programs implementation, because the easily handling of semen is useful for developing new strains. In addition, one of the most important factors is the possibility of store germplasm, ensuring the maintenance of genetic variability of endangered populations (TSAI \& LIN, 2012; MIGAUD et al., 2013). An important species to apply the cryopreservation semen technique is the dourado, Salminus brasiliensis, since it is an important fish in South American river basins. This fish is found in the Paraná, Paraguay and Uruguay basins, the lake system of Lagoa dos Patos and the basin of the upper Chaparé and Mamoré rivers (LIMA et al., 2003). Salminus is a genus of medium to large characiforms (LIMA \& BRITSKI, 2007) and its fishfarming potential and concerns for its conservation in watersheds has stimulated researches with this species. Most studies have been limited to assess the quality of cryopreserved semen by measuring sperm motility. VIVEIROS et al. (2009) indicated that the ideal test for determining the quality of cryopreserved semen was via the egg fertilization rate. According to CAROLSFELD et al. (2003), the fertilization rate using cryopreserved semen may vary with the milt volume used, the activating solution and also with the time of contact between the gametes.

Therefore, the aim of this study was to evaluate the use of varied volumes of cryopreserved sperm, different activator solutions and contact times of these solutions with gametes of dourado to determine the impact of each parameter on the fertilization rate.

\section{MATERIAL AND METHODS}

The experiments were performed at the Freshwater Fish Biology and Fish Culture Laboratory (LAPAD). The broodstock of dourado maintained by LAPAD were used in this experiment, which were composed of wild specimens captured in the upper Uruguay River and direct descendants F1 with weight $3,256 \pm 1,240 \mathrm{~g}$. Males were selected based on release sperm with mild abdominal pressure and produced $10.0 \pm 4.62 \mathrm{~mL}$ milt with concentration of $8.35 \pm 2.46 \times 10^{9}$ spermatozoids $\mathrm{mL}^{-1}$, estimated by counting in Newbauer camera. The females were selected based on bulging and soft abdomens with urogenital papilla opening and produced $455.50 \pm 146.370 \mathrm{~g}$ oocytes with $1,192 \pm 275$ oocytes $\mathrm{g}^{-1}$. For the motility test of cryopreserved semen, the males were not induced before semen collection. Male and female used in the fertilization test were induced to promote final maturation and ovulation. Females received two injections of carp pituitary extract $\left(0.5 \mathrm{mg} \mathrm{kg}^{-1}\right.$ and $\left.5.0 \mathrm{mg} \mathrm{kg}^{-1}\right)$ with 10 hours intervals between applications and the males received $80 \%$ of these doses. In the fertilization tests, gametes from one female and two males were used for each experiment. During induction, the fish were maintained in 1,000L circular tanks at a temperature of $25.5^{\circ} \mathrm{C}$ and dissolved oxygen in average of $7.5 \mathrm{mg} \mathrm{L}^{-1}$.

\section{Cryopreservation}

For semen collection, males were removed from the tank, wrapped in cloth towels and placed on a padded table. After, the urogenital regions were dried using paper towels, semen was removed by applying abdominal pressure and these samples were subsequently cryopreserved. It was only used sperm that exhibited motility time upper than 40 seconds and more that $80 \%$ of motility classified in the score 5 according CAROLSFELD et al. (2003).

For the fertilization experiments with cryopreserved sperm, collection and freezing were performed one hour before the female spawning. In all treatments, semen was mixed with extender solution, loaded into $0.5 \mathrm{~mL}$ straws and stored in dry shipper nitrogen (Taylor-Wharton, model CP 300). Fresh semen samples were maintained in Falcon tubes and stored on ice until the moment of fertilization, which was considered the control treatment.

The extender solution used was a general formula developed for South American migratory fish, consisting of $10 \%(15 \mathrm{~mL}) \mathrm{DMSO}$ (dimethylsulfoxide), $5 \%(7.5 \mathrm{~g})$ of glucose, one hen's egg yolk and $135 \mathrm{~mL}$ of distilled water (CAROLSFELD et al., 2003). The semen and extender solution were mixed at a ratio of one part sperm to four parts extender solution. Each experiment is detailed separately, as follow.

\section{Cryopreserved semen motility test}

Cryopreserved semen samples were stored for 24 hours in nitrogen vapor and then were transferred to liquid nitrogen, where the samples remained stored during one month until the motility test was performed. The thawing was conducted by immersing the frozen semen in water at ambient temperature $\left(25^{\circ} \mathrm{C}\right)$ for 40 seconds. Thereafter, a drop of the sample was placed on a glass slide and mixed with the activator solution $(0.5 \mathrm{~mL})$. The evaluation of sperm motility was performed under the microscope at a magnification of $400 x$. The motility time was repeated four times using semen from different males and for each tested activator solution (water, $0.45 \%$ $\mathrm{NaCl}$ and $1 \% \mathrm{NaHCO}_{3}$ ). 
Different activator solutions in oocyte fertilization In this experiment, the semen was cryopreserved in nitrogen vapor for one hour before fertilization. Samples of $10 \mathrm{~g}$ of oocytes from one female were fertilized with fresh and cryopreserved semen, and also activated with different solutions. The oocytes were distributed in $500 \mathrm{~mL}$ plastic beaker and fertilized with $0.05 \mathrm{~mL}$ of fresh semen (control) or with $0.10 \mathrm{~mL}$ of cryopreserved semen. In both cases, the activation was conducted with three different activators solutions: water, $0.45 \% \mathrm{NaCl}$ and $1 \% \mathrm{NaHCO}_{3}$. For the cryopreserved semen, thawing was performed as described previously and added to the oocytes. Afterward, were added $100 \mathrm{~mL}$ of the different activators solutions which were maintained for 3 minutes. Subsequently, the activator solutions were removed and the eggs were transferred to incubators. It was used 10 liter cone incubator with continuous water flow. All tests were performed in triplicate.

Different volumes of cryopreserved semen in fertilization

In this experiment, the semen was cryopreserved in nitrogen vapor one hour before de fertilization. Samples of $10 \mathrm{~g}$ of oocytes were fertilized with different volumes of cryopreserved semen and compared with fresh semen. The oocytes were distributed in $500 \mathrm{~mL}$ plastic beaker and fertilized with $0.05 \mathrm{~mL}$ of fresh semen or $0.025,0.05$ or $0.10 \mathrm{~mL}$ of cryopreserved semen. Activation of the gametes was conducted only with water.

Activator solution type and maintenance time on the fertilization rate

Samples of $10 \mathrm{~g}$ of oocytes were distributed in $500 \mathrm{~mL}$ plastic beaker fertilized using fresh sperm $(0.05 \mathrm{~mL})$ and cryopreserved semen $(0.10 \mathrm{~mL})$. Activation of gametes was performed with water or $1 \%$ $\mathrm{NaHCO}_{3}$ solution. Both solutions were maintained in contact with gametes for 30, 60, 180 and 300 seconds.

Data analysis

The motility time of the cryopreserved semen was used to determine the best activator solution and the fertilization rate was used to determinate the best method of fertilization. The evaluation of the fertilization rate was performed approximately seven hours after insemination (blastopore stage closure) by counting the eggs with normal development of a sample of 260 eggs from each incubator.

The data that presented normal distribution was submitted to Anova and significance level was set to $\mathrm{P}<0.05$, followed by the Duncan test. When normal distribution was not observed the KruskalWallis test was used followed by the Conover-Iman test. Multifactorial ANOVA was used to analyze the interaction between activator solution and maintenance time on the fertilization rate.

To eliminate the effect of oocyte quality on the results, the adjustment of fertilization rate was calculated. The control sample of fresh semen was considered $100 \%$ and the cryopreserved semen samples were corrected by the control rate (CAROLSFELD et al., 2003).

\section{RESULTS AND DISCUSSION}

Cryopreserved semen motility test

The cryopreservation and thawing procedures were effective in promoting the motility of dourado semen, as the motility was verified for all activators. The $0.45 \% \mathrm{NaCl}$ and $1 \%$ $\mathrm{NaHCO}_{3}$ activators provided similar motility times $(104 \pm 20.81 \mathrm{~s}$ and $112 \pm 10.95 \mathrm{~s}$ respective), which were three times higher than the semen activated with water $(36 \pm 5.35 \mathrm{~s})$.

Different activator solutions in oocyte fertilization

The use of differentactivator solutions presented an influence on the fertilization rate (Table 1) but fresh and cryopreserved semen presented the same standard. The fresh or cryopreserved semen activated by water presented higher fertilization rate following by $1 \%$ $\mathrm{NaHCO}_{3}$ activator. The $0.45 \% \mathrm{NaCl}$ activator solution resulted in extreme lower fertilization rate to both types of semen, even though inducing the highest motility time for cryopreserved semen in the motility test.

Table 1 - Fertilization rate (mean \pm SD) of dourado eggs fertilized with fresh or cryopreserved semen with different activator solutions.

\begin{tabular}{llcl}
\hline Semen & $\begin{array}{l}\text { Activator } \\
\text { solutions }\end{array}$ & Replica & Fertilization $(\%)^{2}$ \\
\hline \multirow{2}{*}{ Fresh $^{1}$} & water & 3 & $\begin{array}{l}100.0 \pm 7.1^{\mathrm{a}} \\
(64.1)\end{array}$ \\
& $1 \% \mathrm{NaHCO}_{3}$ & 3 & $46.6 \pm 2.7^{\mathrm{b}}$ \\
& $0.45 \% \mathrm{NaCl}$ & 3 & $5.3 \pm 2.8^{\mathrm{e}}$ \\
& & & \\
Cryopreserved & $1 \% \mathrm{NaHCO}_{3}$ & 3 & $23.7 \pm 8.2^{\mathrm{c}}$ \\
& $0.45 \% \mathrm{NaCl}^{2}$ & 3 & $16.7 \pm 2.7^{\mathrm{d}}$ \\
& & 3 & $1.9 \pm 0.2^{\mathrm{f}}$ \\
\hline
\end{tabular}

1 - The real average fertilization rate observed in the control treatment is shown in parentheses.

2 - The different letters indicate statistically significant differences $(\mathrm{P}<0.05$ - Kruskal-Wallis test - post hoc ConoverIman). 
Different volumes of cryopreserved semen during fertilization

The highest fertilization rate using cryopreserved semen was obtained using the $0.05 \mathrm{mLachieving} 22.61 \pm 7.79 \%$, which was superior that than obtained for $0.10 \mathrm{~mL}$ with $0.33 \pm 0.57 \%$. The volume $0.025 \mathrm{~mL}$ of cryopreserved semen was not fertilized.

The effect of maintenance time and activator solution type on the fertilization rate

There was no interaction effect between activator solution and maintenance time. Only the maintenance time had an influence on the fertilization rate, with 60 and 30 seconds presenting higher fertilization rate that 180 and 300 seconds (Table 2).

The cryoprotectant solution, freezing and thawing procedures used in this study allowed to obtain living sperm after thawing. The sperm motility values observed in this study after one month of freezing were higher than those obtained by SANCHEZ et al. (2009) for fresh semen from Salminus brasiliensis. According to VIVEIROS et al. (2009), among the several cryoprotectant solutions tested for preserving the semen of $\boldsymbol{S}$. brasiliensis, the mixture of glucose with DMSO provided the best results.

Activation of cryopreserved semen from dourado using an activator solution of $1 \%$ $\mathrm{NaHCO}_{3}$ exhibited a motility time value similar to that activated with $0.45 \% \mathrm{NaCl}$, and both of these values were higher than water. This fact can be associated with a lower osmotic difference between activator to cytoplasm, preserving the integrity of the cytoplasmic membrane of spermatozoa (MURGAS et al., 2007). A similar result was observed for the

Table 2 - Fertilization rate (mean \pm SD) of dourado eggs fertilized with cryopreserved sperm using different solutions and maintenance times in the activation of gametes. Fertilization rate of the control test (fresh semen activated with water and maintained during 180 seconds) $=88.8 \% \pm 7.4$.

\begin{tabular}{llc}
\hline Semen & Treatments & Fertilization $(\%)^{1}$ \\
\hline & Water & $24.9 \pm 8.7^{\mathrm{a}}$ \\
& $1 \% \mathrm{NaHCO}_{3}$ & $20.3 \pm 6.2^{\mathrm{a}}$ \\
Cryopreserved & 30 & -------- Activator Solution -------------- \\
& 60 & $25.6 \pm 5.0^{\mathrm{a}}$ \\
& 180 & $28.3 \pm 8.1^{\mathrm{a}}$ \\
& 300 & $16.7 \pm 3.0^{\mathrm{b}}$ \\
& & $17.0 \pm 6.0^{\mathrm{b}}$ \\
\hline
\end{tabular}

1 - Different letters indicate statistically significant differences $(\mathrm{P}<0.05-$ Multifactor Anova / Duncan test $)$. activation of cryopreserved semen of Leporinus elongatus (MURGAS et al., 2007) and for Brycon insignis (VIVEIROS et al., 2011). Nevertheless, CAROLSFELD et al. (2003) have not found a difference between dourado semen activated with water or $1 \% \mathrm{NaHCO}_{3}$.

The highest fertilization rate of dourado eggs was observed using $0.05 \mathrm{~mL}$ of semen, the equivalent of $1 / 2$ straw for $10 \mathrm{~g}$ of oocytes, which represents 35,000 spermatozoa for each oocyte. Studies have demonstrated the importance of an adequate relationship between semen and oocytes (RINCHARD et al., 2005; SANCHEZ et al., 2009) and also between semen and activator solution volumes (HOYSAK \& LILEY, 2001; CASSELMAN et al., 2006).

SANCHEZ et al. (2009) tested different ratio between fresh sperm and oocytes from dourado and recommended the ratio of 30,700 spermatozoa per oocyte to obtain the best fertilization rates. A similar spermatozoa-per-oocyte ratio was verified in this study and it was true for all conditions, despite the differences in quality noted between fresh and cryopreserved semen.

VIVEIROS \& GODINHO (2009) have argued that the knowledge of sperm quality and minimum sperm:egg ratio is important to maximize the use of males without reducing hatching rates. According to TIERSCH (2000), approximately 40$90 \%$ of fresh water fish sperm is damaged by the cryopreservation process. Because of the loss of quality in cryopreserved gametes, it becomes even more important to define the ideal relationship between the gametes (KOPEIKA et al., 2007). Based on this fact, it was expect that a greater volume of the semen would be necessary for obtaining a high fertilization rate, but this prediction was not observed for dourado.

The increased volume of cryopreserved semen during fertilization involved an increase in the proportional volume of extender solution. The cryoprotectant solutions have the characteristic of being toxic to gamete cells (VIVEIROS et al., 2009). RIBEIRO \& GODINHO (2003) observed a reduction of more than $30 \%$ in the percentage of motile sperm of Leporinus macrocephalus when the concentration of DMSO in the extender solution increased from $10 \%$ to $15 \%$.MAGYARY et al. (1996) reported a significant decrease in fertilization rates for common carp eggs by increasing cryopreserved semen volumes and attributed this fact to the toxicity of DMSO.

Another possible influence is related to semen osmolality. According to COSSON (2010), the freshwater fish osmotic concentration of seminal plasma is $300 \mathrm{mOsm} \mathrm{L}^{-1}$ and the better motility is 
observed when the osmolality of the medium in which activation occurs is around $10 \mathrm{mOsm} \mathrm{L}^{-1}$. VIVEIROS et al. (2009) observed a reduction of $22 \%$ in the motility rate of dourado semen when activated with a solution containing $154 \mathrm{mM} \mathrm{NaCl}$ compared with semen activated by water. For another Characiform, Brycon orbignyanus, GONÇALVES et. al. (2013) found the best motility rates around $135 \mathrm{mOsm}$, with fast fall in superior osmolality. The bigger volume of cryopreserved semen used in the present experiments resulted in an increased of the osmolality in fertilizer medium, which can induce to a decrease in the fertilization rate. An alternative approach for increasing the number of spermatozoa with no effect on the toxicity and osmolality, caused by increasing the cryoprotectant solution volume, is to reduce the dilution of semen within the cryoprotectant solution, which is typically maintained at 1:4 (semen:extender). CAROLSFELD et al. (2003), affirmed that the relationship between semen and extender solution for South American fish can vary from 1:3 to 1:5, although VIVEIROS et al. (2011) effectively used a dilution 1:10 in the cryopreservation of Brycon insignis sperm. According to VIVEIROS et al. (2009), an adequate combination between different activator solutions and cryoprotectants could reduce the toxic effects of cryoprotectants, thereby improving the fertilization rates.

Further studies testing the reduction of the dilution between semen and extender solution for $\boldsymbol{S}$. brasiliensis, as well as an increase activator solution volume at the moment of fertilization could be important for reducing the toxic effect of the extender solution, allowing better fertilization rates.

The maintenance time that the activator solution was in contact with the gametes affected the fertilization rate of dourado eggs, with the best result obtained when the activator solution was maintained for 60 seconds. These results are in accordance with the sperm motility time verified in this research. The increase in exposure time of the eggs to the extender solution can intensify the toxic effects of the cryoprotectants (PLACHINTA et al., 2004), which would have an adverse effect on fertilization.

\section{CONCLUSION}

The better activator solution for activation sperm motility of dourado is water and $1 \% \mathrm{NaHCO}_{3}$. The ideal relationship between cryopreserved semen and oocytes considering the average concentration of sperm per milliliter is $0.05 \mathrm{~mL}$ semen $(1 / 2 \mathrm{straw})$ for $10 \mathrm{~g}$ of oocytes, which represents a ratio of 35,000 spermatozoa per oocyte.
The optimum maintenance time of the activator solution with the gametes of dourado was of 30 and 60 seconds. Increasing maintenance time resulted in reductions in fertilization rates.

\section{ACKNOWLEDGMENTS}

The authors are grateful to the staff of the Freshwater Fish Biology and Fish Culture Laboratory (LAPAD) for collaboration in the execution of these experiments and to the $\mathrm{CNPq}$ for providing doctoral and productivity grants to the authors.

\section{REFERENCES}

CAROLSFELD, J. et al. Cryopreservation of sperm in Brazilian migratory fish conservation. Journal of Fish Biology, v.63, p.472-481, 2003. Available from: <http://onlinelibrary.wiley.com/ doi/10.1046/j.1095-8649.2003.00170.x/pdf $>$. Accessed: Feb. 18, 2013. doi: 10.1046/j.1095-8649.2003.00170.x.

CASSELMAN, S.J. et al. Sperm quality influences male fertilization success in walleye (Sander vitreus). Canadian Journal of Fisheries and Aquatic Science, v.63, n.9, p.2119-2125, 2006. Available from: <http://www.nrcresearchpress.com/doi/pdf/10.1139/ f06-108>. Accessed: Feb. 18,2013. doi: 10.1139/f06-108.

COSSON, J. Frenetic activation of fish spermatozoa flagella entails short-term motility, portending their precocious decadence. Journal of Fish Biology, v.76, p.240-279, 2010. Available from: <http://onlinelibrary.wiley.com/doi/10.1111/ j.1095-8649.2009.02504.x/pdf>. Accessed: Jul. 30, 2014. doi; 10.1111/j.1095-8649.2009.02504.x.

GONCALVES, A.C.S. et al. Initiation and suppression of sperm motility is osmolality-dependent in two South American fish species: streaked prochilod Prochilodus lineatus and piracanjuba Brycon orbignyanus. Animal Reproduction, v.10, p.62-70, 2013. Available form: $<$ http://www.cbra.org.br/pages/publicacoes/ animalreproduction/issues/download/v10n1/pag62-70\%20 (AR543).pdf>. Accessed: Jul. 30, 2014.

HOYSAK, D.J.; LILEY, N.R. Fertilization dynamics in sockeye salmon and a comparison of sperm from alternative male phenotypes. Journal of Fish Biology, v.58, p.12861300, 2001. Available from: <http://onlinelibrary.wiley.com/ doi/10.1111/j.1095-8649.2001.tb02286.x/pdf>. Accessed: Feb. 18, 2013.doi:10.1111/j.1095-8649.2001.tb02286.x.

KOPEIKA, E. et al. Sperm cryopreservation of fish. In: DAY, J.G.; STACEY, G.N. (Eds.). Cryopreservation and freeze-drying protocols. Series: methods in molecular biology. Totow: Humana, 2007. V.368, p.203-217.

LIMA, F.C.T. et al. Genera incertae sedis in Characidae. In: REIS, R.E.et al. (Eds.).Check list of the freshwater fishes of South and Central America. Porto Alegre: Edipucrs, 2003. p.106-169.

LIMA, F.C.T.; BRITSKI, H.A. Salminus franciscanus, a new species from the rio São Francisco basin, Brazil (Ostariophysi: Characiformes: Characidae). Neotropical Ichthyology, v.5, n.3, p.237-244, 2007. Available from: <http://www.scielo.br/scielo. php? script $=$ sci_arttext\&pid $=$ S167962252007000300001\&lng $=\mathrm{e}$ n\&nrm=iso $>$. Accessed: Feb. 18, 2013. doi: org/10.1590/S167962252007000300001 . 
MAGYARY, I. et al. Cryopreservation of common carp (Cyprinus carpio L.) sperm: II. Optimal conditions for fertilization. Journal of Applied Ichthyology, v.12, p.117-119, 1996. Available from: $<$ http://onlinelibrary.wiley.com/doi/10.1111/j.14390426.1996. tb00073.x/pdf>. Accessed: Feb. 18, 2013.doi: 10.1111/j.14390426.1996.tb00073.x.

MIGAUD, H. et al. Gamete quality and broodstock management in temperate fish. Revista Aquaculture, v.5 supl.s1, p.s194-s223, 2013. Available from: <http://dx.doi.org/10.1111/raq.12025>. Accessed: Jul. 18, 2013. doi: 10.1111/raq.12025.

MURGAS, L.D.S. et al.Criopreservação do sêmen de curimba (Prochilodus lineatus) mediante adição de diferentes diluidores, ativadores e crioprotetores. Revista Brasileira de Zootecnia, v.36, n.3, p.526-531, 2007. Available from: $<$ http://www.scielo.br/scielo. php?script $=$ sci_arttext\&pid=S1516-35982007000300002\&lng $=\mathrm{e}$ n\&nrm $=$ iso $>$. Accessed: Feb. 18, 2013. doi: org/10.1590/S151635982007000300002 .

NASCIMENTO, A.F. et al. Out-of-season sperm cryopreserved in different media of the Amazonian freshwater fish pirapitinga (Piaractus brachypomus). Animal Reproduction Science, v.118, p.324-329, 2010. Available from: <http://www.sciencedirect.com/ science/article/pii/S0378432009001845>. Accessed: Feb. 18, 2013. doi: 10.1016/j.anireprosci.2009.07.002.

PLACHINTA, M. etal. Studies on cryoprotectant toxicity tozebrafish (Danio rerio) oocytes. CryoLetters, v.25, n.6, p.415-424, 2004. Available from: <http://www.ingentaconnect.com/content/cryo/ cryo/2004/00000025/00000006/art00004>.Accessed: Jul. 31, 2014.

RIBEIRO, R.I.M.A.; GODINHO, H.P. Cryopreservation of semen from the testis piauçu teleost Leporinus macrocephalus. Arquivo Brasileiro de Medicina Veterinária e Zootecnia, v.55, n.1, p.1-7, 2003. Available from: $<$ http://www.scielo.br/scielo.php? script $=$ sci arttext\&pid=S0102-09352003000100011>. Accessed: Feb. 18, 2013. doi:10.1590/S0102-09352003000100011.

RINCHARD, J.et al. Optimization of fertilization success in Sander vitreus is influenced by the sperm: egg ratio and ova storage.
Journal of Fish Biology, v.67, p.1157-1161, 2005. Available from: <http://dx.doi.org/10.1111/j.0022-1112.2005.00800.x>. doi: 10.1111/j.0022-1112.2005.00800.x.

SANCHEZ, E.A. et al. Dose inseminante para fertilização artificial de ovócitos de dourado. Revista Brasileira de Zootecnia, v.38, n.11, p.2091-2098, 2009. Available from: $<$ http://www.scielo.br/scielo.php?script $=$ sci_arttext\&pid=S151635982009001100003\&lng=en\&nrm=iso $>$. Accessed: Feb. 18, 2013. doi: 10.1590/S1516-35982009001100003.

TIERSCH, T.R. Introduction. In: TIERSCH, T.R.; MAZIK, P. (Eds.). Aquatic Species in cryopreservation. Louisiana: World Aquaculture Society, 2000. p.14-26.

TSAI, S.; LIN, C. Advantages and applications of cryopreservation in fisheries science. Brazilian Archives of Biology and Technology, v.55, n.3, p.425-434, 2012. Available from: <http:// www.scielo.br/scielo.php?script $=$ sci_arttext\&pid $=\mathrm{S} 1516$ 89132012000300014\&lng=en\&tlng=en>. Accessed: Jul. 18, 2013. doi: $10.1590 / \mathrm{S} 1516-89132012000300014$

VIVEIROS, A.T.M. et al. Sensibilidade dos espermatozoides de dourado (Salminus brasiliensis) a diferentes soluções crioprotetoras. Arquivo Brasileiro de Medicina Veterinária e Zootecnia, v.61, p.883-889, 2009. Available from: <http:// www.scielo.br/scielo.php?script $=$ sci_arttext\&pid $=$ S0 $102-$ 09352009000400016\&lng $=$ en $\& n+m=$ iso $>$. Accessed: Feb. 18, 2013. doi: 10.1590/S0102-09352009000400016.

VIVEIROS, A.T.M.; GODINHO, H.P. Sperm quality and cryopreservation of Brazilian freshwater fish species: a review. Fish Physiology and Biochemistry, v.35, p.137-150, 2009. Available from: <http://dx.doi.org/10.1007/s10695-008-9240-3>. Accessed: Feb. 18, 2013. doi: 10.1007/s10695-008-9240-3.

VIVEIROS, A.T.M. et al. Sperm cryopreservation of tiete tetra Brycon insignis (Characiformes): effects of cryoprotectants, extenders, thawing temperatures and activating agents on motility features. Aquaculture Research, v.42, p. 858-865, 2011. Available from: <http://dx.doi.org /10.1111/j.1365-2109.2010.02761.x>. Accessed: Feb. 18, 2013. doi: 10.1111/j.1365-2109.2010.02761.x. 